\title{
Disaster and Distance Learning: Exploratory Factors Analysis of Online Learning Effectiveness During Pandemic
}

\author{
Eko Budi Sulistio ${ }^{1, *}$ Simon Sumanjoyo Hutagalung ${ }^{2}$ \\ ${ }^{1}$ Department of Public Administration, University of Lampung, Lampung, Indonesia \\ ${ }^{2}$ Department of Public Administration, University of Lampung, Lampung, Indonesia \\ Corresponding author. Email: eb.sulistio@fisip.unila.ac.id
}

\begin{abstract}
Various efforts have been made to continue to carry out learning during the pandemic. It is crucial to evaluate the correlated factors in supporting the effectiveness of distance learning during this pandemic. The survey research was conducted using online questionnaires to students at the University of Lampung. Respondents in this study were taken as many as 100 respondents. The data analysis carried out includes statistical analysis of exploratory factors analysis to determine the variation in the grouping of factors from the survey data obtained. Data analysis was carried by JASP 0.13 software. Based on the data, there are two-dimensional groupings in the factors that affected the effectiveness of online learning during the pandemic. The first dimension includes the environment for students to do online learning. The second dimension includes students' internal factors and learning support resources. The most dominant factor that affects the learning effectiveness is environmental conditions, especially the social and physical environment. Meanwhile, the curriculum is not considered an influential factor in the effectiveness of the learning. Intervention is needed in the environment in which students learn and the mental condition to optimize the effectiveness of learning during the pandemic.
\end{abstract}

Keywords: Distance Learning, Disaster Resilience, Exploratory Factor Analysis, University

\section{INTRODUCTION}

In the 2020 and 2021 pandemic era, the government has intervened education process in Indonesia due to the rapid spread of the corona virus. Through the Ministry of Education and Culture, the government made various learning adjustments during the pandemic as stated in Circular Letter Number 2 of 2020 concerning Prevention and Handling of COVID-19 within the Ministry of Education and Culture and Circular Letter Number 3 of 2020 concerning Prevention of COVID-19 in Education Units. One form of new learning activity is learning from home (online learning) [1]. Minister of Education and Culture Nadiem Makarim said that there were nine policies and programs implemented during the COVID-19 pandemic. It does not stop there, and the government has a program to accelerate economic recovery in Indonesia due to the impact of the COVID-19 pandemic, namely the National Economic Recovery Program (PEN). The government wants to focus on many sectors for this recovery, one of which is the Education sector [2]. The PEN Program in the education sector is subsidies for students in the form of internet quotas and the Wage Subsidy Assistance (BSU) program for educators [3].

Online learning is the most popular format of distance learning [4]. The distance learning system is a system that has existed since the middle of the 18th century [5]. Since the beginning, distance learning has always used technology to implement learning, from the most straightforward technique to the latest. In brief, the history of the development of distance learning can be grouped according to the dominant technology it uses. Taylor in Firman \& Rahayu (2020), for example, the distance learning generation 
divide into five groups (5) generations, namely: (1) correspondence model, (2) multi-media model, (3) tele-learning model, (4) model flexible learning, and (5) more innovative flexible learning models. In the fourth and fifth generations of distance learning, jargon very popular in the community, such as elearning, online learning, and mobile learning were born, which further popularized the distance learning phenomenon [6].

Online learning is not just sharing learning material on the internet network. In addition to online learning materials, there is also a process of online teaching and learning activities [7]. So, the main difference between online learning and just online learning material is the interaction that occurs during the learning process [8]. Interaction in learning consists of interactions between the learner and the teacher and facilitator (teacher), with other fellow learners, and with the learning material itself Moore (1989) in [9]. The three types of interactions that occur in online learning will create a learning experience, although it is realized that there will be many factors that can affect the effectiveness of the learning. Nevertheless, online learning policies are not as easy as imagined. In some cases, it is possible for groups of students who are less likely to engage in collaborative learning, student-faculty interaction, and discussion with a diverse range of others, especially when compared to their more traditional classroom counterparts. The students' variation of engagement in larger online courses also reported less exposure to effective teaching practices and lower quality of interaction[10]. Online learning provides convenience in providing information transfer in various situations and conditions. Various benefits of online learning facilities supported by various platforms ranging from discussion to face-toface virtually. However, this needs to be evaluated and adjusted to local conditions, considering the ability of parents to provide different online learning facilities [11].

Several things affect the way a student learns, including the influence of external factors and internal factors of the student. According to Suryabrata (2002) in [12] the factors that influence the way of learning include the following. a. Factors from within students: Psychological factors (intellectual intelligence (IQ), learning ability, learning motivation, attitudes and feelings, interests and conditions due to sociocultural conditions). Physiological factors are divided into 2, namely: first, the physical condition behind the learning activity where a fair physical condition will have a different effect on a sick physical condition. The second is the state of certain physiological functions. b. Factors from outside students: Factors regulating teaching and learning in schools in the form of teaching curriculum, school discipline, learning facilities, student grouping. Social factors in schools are the school system, students' social status, teacher-student interactions. Situational factors are economic conditions, circumstances of time and place, as well as the environment. Of the many options for these factors, it is crucial to analyze which factors support the effectiveness of distance learning during this pandemic. This research is expected to provide recommendations for higher education policies, especially interventions that must be carried out on students.

\section{RESEARCH METHODS}

This research was conducted using quantitative methods with survey instruments. In this study, the concept of learning effectiveness from Suryabrata (2002) was used with the identification of the following factors:

Table 1. Factors Identification in Online Learning Effectiveness

\begin{tabular}{|l|l|}
\hline No. & \multicolumn{1}{|c|}{ Factors Name } \\
\hline 1. & Physiological conditions \\
\hline 2. & Psychological conditions \\
\hline 3. & Motivating conditions \\
\hline 4. & cognitive readiness/reason \\
\hline 5. & physical environmental conditions \\
\hline 6. & social environmental conditions \\
\hline 7. & natural environmental conditions \\
\hline 8. & curriculum readiness \\
\hline 9. & readiness of infrastructure facilities \\
\hline 10. & Teaching staff readiness \\
\hline
\end{tabular}

Respondents in this study were taken as many as 100 respondents. The criteria proposed in this study were: (1). Students who are still actively studying at tertiary institutions at the University of Lampung, (2). Minimum age 20 years, (3). Attending lectures actively online on semester runs during a pandemic. The survey was carried out in two-time frames from March 2021 to May 2021. The questionnaire was made using the Likert scale, which is a scale that shows consumer responses to the characteristics of choice. The data analysis carried out includes statistical analysis of exploratory factors analysis to determine the variation in the grouping of factors from the survey data obtained. Data analysis using JASP 0.13 software which is considered qualified to perform the EFA test. An EFA is a statistical method used to build a structure model consisting of a set or many variables. Efas are one method of factor analysis to identify the relationship between manifest variables or indicator variables in building a construct[13]. EFA 
provides information About how many factors are needed to represent the data, so that all the variables measured are related to each factor using the estimated loading factor. The results of this EFA test will then display the dominant categorization grouping that reflects the correlation between variables.

\section{RESULTS AND DISCUSSION}

Based on the survey conducted, it can be seen that the profile of the respondents who filled out this questionnaire. In the gender category, it appears that the dominant group of respondents is women (63\%), while in the category of the type of access they have in online learning, the dominant category is internet access at home (82\%). In computer literacy, the dominant category is in the intermediate category (70.8\%). This category means individuals who have often used computers and their applications for routine activities and unique applications that do not require high skills. In the learning style category, it seems dominant in the visual category (61.5\%). In detail, this can be summarized in the following table:

Table 2. Respondent Profile

\begin{tabular}{|r|l|l|r|r|}
\hline No & Category & \multicolumn{1}{|c|}{ Sub Cat } & Qty & \multicolumn{1}{c|}{$\%$} \\
\hline 1 & Gender & Male & 27 & 28.1 \\
\hline 2 & $\begin{array}{l}\text { Location of } \\
\text { Access }\end{array}$ & Women & 61 & 63.5 \\
\hline & & House & 1 \\
\hline & & $\begin{array}{l}\text { Public Location With } \\
\text { Free Wifi }\end{array}$ & 82 & 85.4 \\
\hline & & $\begin{array}{l}\text { Location with paid } \\
\text { Wifi }\end{array}$ & 6 & 6.1 \\
\hline & & Others & 6 & 6.3 \\
\hline 3 & $\begin{array}{l}\text { Computer } \\
\text { literacy }\end{array}$ & Elementary & 14 & 14.6 \\
\hline & & Intermediate & 68 & 70.8 \\
\hline & & Expert & 14 & 14.6 \\
\hline 4 & $\begin{array}{l}\text { Learning } \\
\text { Styles }\end{array}$ & Visual & 0 & 0 \\
\hline & & Verbal & 59 & 61.5 \\
\hline & & Experimental & 18 & 18.8 \\
\hline & & Motoric & 10 & 9.4 \\
\hline
\end{tabular}

\subsection{Assumption Test}

An assumption test is then carried out to determine the adequacy of the sample used. The assumption test was carried out using the KaiserMeyer-Olkin Test and the Bartlet Test. The Kaiser Meyer Olkin Measure of Sampling (KMO) is the index of the distance comparison between the correlation coefficient and its partial correlation coefficient. If the sum of the squares of the partial correlation between all variable pairs is of small value when compared to the sum of the squares of the correlation coefficient, it will result in a KMO value close to 1 . The standard in the Kaiser Meyer Olkin test is that the overall MSA score must be above 0.5 , while the data in the following table has a score of 0.776 . This indicates if the sample used is sufficient and can be analyzed.

Table 3. Kaiser-Meyer-Olkin Assumption Test

\begin{tabular}{ll}
\hline & MSA \\
\hline Overall MSA & 0.776 \\
Physiological conditions & 0.821 \\
Psychological conditions & 0.591 \\
Motivating conditions & 0.835 \\
cognitive readiness/reason & 0.807 \\
physical environmental conditions & 0.692 \\
social, environmental conditions & 0.663 \\
natural environmental conditions & 0.855 \\
curriculum readiness & 0.838 \\
readiness of infrastructure facilities & 0.799 \\
Teaching staff readiness & 0.887
\end{tabular}

Bartlett test was conducted to determine the relationship between variables correlated with each other, where the standard is less than 0.005 . From the data in the following table, it appears that if it is lower than 0.001, it can be said that there is a mutual correlation between variables.

Table 4. Bartlett's test

\begin{tabular}{ccc}
\hline $\mathbf{2}$ & $\mathbf{d f}$ & $\mathbf{p}$ \\
\hline 340.916 & 45.000 & $<.001$ \\
\hline
\end{tabular}

\subsection{Data Analysis}

The results of factor testing are obtained in the following table, and it appears that there is a grouping into two factors. The first factor appears to be physical environmental conditions, social, environmental conditions and natural environmental conditions. The second factor appears to group the variables of physiological conditions, psychological conditions, motivating conditions, cognitive readiness/reason and readiness of infrastructure facilities and teaching staff readiness. In contrast, the unrelated variable is curriculum readiness. It also appears that the first factor with the most significant weight is in social, environmental conditions, 
physical environmental conditions, while the second factor with the most significant weight is Motivating conditions and Psychological conditions.

Table 5. Factor Loading in Online Learning

\begin{tabular}{|c|c|c|c|}
\hline & $\begin{array}{c}\text { Factor } \\
1\end{array}$ & $\begin{array}{c}\text { Factor } \\
2\end{array}$ & Uniqueness \\
\hline Physiological conditions & & 0.447 & 0.769 \\
\hline Psychological condition & & 0.577 & 0.665 \\
\hline Motivating conditions & & 0.703 & 0.452 \\
\hline cognitive readiness/reason & 0.402 & 0.504 & 0.584 \\
\hline $\begin{array}{l}\text { physical environmental } \\
\text { conditions }\end{array}$ & 0.700 & & 0.502 \\
\hline $\begin{array}{l}\text { social, environmental } \\
\text { conditions }\end{array}$ & 0.997 & & 0.005 \\
\hline $\begin{array}{l}\text { natural environmental } \\
\text { conditions }\end{array}$ & 0.584 & 0.462 & 0.445 \\
\hline curriculum readiness & & & 0.705 \\
\hline $\begin{array}{l}\text { readiness of infrastructure } \\
\text { facilities }\end{array}$ & & 0.527 & 0.592 \\
\hline Teaching staff readiness & & 0.552 & 0.672 \\
\hline
\end{tabular}

The table can be categorized if the first factor is related to the mental and physical condition of students participating in distance learning. Meanwhile, the second factor seems to group the environmental conditions in which students carry out distance learning. The grouping can be illustrated from the following diagram:

Figure 1. Path Diagram Of Factor in Online Learning Effectiveness

The diagram shows the grouping of factors that occur, where PC1 is an environmental factor for

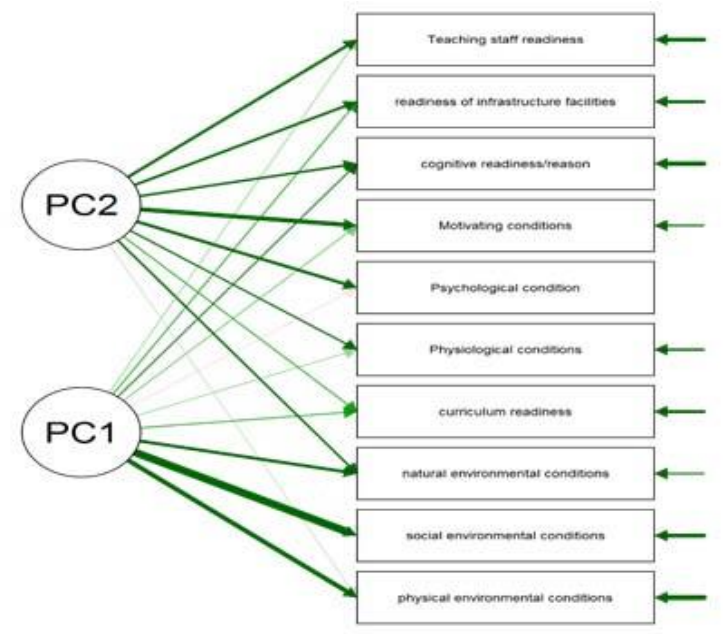

students doing online learning and PC2 is an internal factor for students and learning support resources. It also appears that environmental conditions have the thickest weight, especially the social environment and physical environment. It also shows that environmental conditions are factors that are still difficult to the condition in distance learning. The social, geographical and demographic background of student domicile appears to be a significant challenge. Then, pandemics create the mental state of college students who tend to have difficulty communicating more openly, resulting in loneliness and depression. This identification will be necessary for policy processes at the strategic and operational levels. So that some recommendations can be made as follows; (a). The conduciveness of the social and physical environment is a factor that students feel is very dominant in the effectiveness of online learning. Optimal collaboration is needed between families, teachers and managers of the environment where students live is essential [14], (b). Students' internal conditions, which include motivation and psychological conditions, should be managed through a counselling system or psychological assistance provided by the university [15], (c). The curriculum is not considered a factor that affects the learning process, and this is considering the pandemic conditions have created conditions that are not ideal for the implementation of the curriculum as a whole [16]. Online learning in pandemic times is becoming popular and a top choice because of its potential to provide more flexible access to virtual learning content and interactions[17]. But it is becomes very important to note is the carrying capacity of the environment and mental support to the group of students who must follow the online learning process. It is necessary to consider the choice of companion learning patterns and examine the efficacy of online learning in educating students in a more corrective model to current problems.

\section{CONCLUSION}

Based on the data, it is known that there are twodimensional groupings in the factors that affect the effectiveness of online learning during the pandemic. The first dimension includes the environment for students doing online learning. The second dimension includes students' internal factors and learning support resources. The most dominant factor that affects the learning effectiveness is environmental conditions, especially the social and physical environment. Meanwhile, the curriculum is not considered an influential factor in the effectiveness of the learning. Intervention is needed in the environment in which students learn and the mental condition to optimize the effectiveness of learning during the pandemic. In the future, identifying this factor can be a conceptual consideration for distance education policy research to prepare the initial conditions for factors that can be an obstacle to the effectiveness of learning. While for the preparation of 
policies at the operational level can be a reference for evaluating distance learning policies in the future.

\section{ACKNOWLEDGMENT}

The author would like to express his gratitude to LPPM Unila for supporting this research funding through the Dipa BLU Unggulan Universitas Lampung 2021 scheme and the respondents who have participated voluntarily in this research.

\section{REFERENCES}

[1] F. Firman and S. Rahayu, 'Pembelajaran Online di Tengah Pandemi Covid-19', Indonesian Journal of Educational Science (IJES), vol. 2, no. 2, Art. no. 2, Apr. 2020, doi: 10.31605/ijes.v2i2.659.

[2] R. Pakpahan and Y. Fitriani, 'ANALISA PEMANFAATAN TEKNOLOGI INFORMASI DALAM PEMBELAJARAN JARAK JAUH DI TENGAH PANDEMI VIRUS CORONA COVID-19', Journal of Information System, Applied, Management, Accounting and Research, vol. 4, no. 2, Art. no. 2, May 2020.

[3] K. L. G. M. Z. Atsani, 'TRANSFORMASI MEDIA PEMBELAJARAN PADA MASA PANDEMI COVID-19', al-Hikmah: Jurnal Studi Islam, vol. 1, no. 1, Art. no. 1, Jul. 2020.

[4] A. N. Bahasoan, W. Ayuandiani, M. Mukhram, and A. Rahmat, 'Effectiveness of Online Learning In Pandemic Covid-19', International Journal of Science, Technology \& Management, vol. 1, no. 2, Art. no. 2, Jul. 2020, doi: 10.46729/ijstm.v1i2.30.

[5] H. Baber, 'Social interaction and effectiveness of the online learning - A moderating role of maintaining social distance during the pandemic COVID-19', Asian Education and Development Studies, vol. ahead-of-print, no. ahead-of-print, Jan. 2021, doi: 10.1108/AEDS09-2020-0209.

[6] H. Yulia, 'Online Learning to Prevent the Spread of Pandemic Corona Virus in Indonesia', ETERNAL (English Teaching Journal), vol. 11, no. 1, Art. no. 1, May 2020, doi: 10.26877/eternal.v11i1.6068.

[7] Y. Pujilestari, 'Dampak Positif Pembelajaran Online Dalam Sistem Pendidikan Indonesia Pasca Pandemi Covid-19', 'ADALAH, vol. 4, no. 1, Art. no. 1, Apr. 2020, doi: 10.15408/adalah.v4i1.15394.

[8] K. Arizona, Z. Abidin, and R. Rumansyah, 'Open Journal Systems', Jurnal Ilmiah Profesi
Pendidikan, vol. 11, 2020, doi: https://doi.org/10.29303/jipp.v5i1.111.

[9] N. K. S. Astini, 'Tantangan Dan Peluang Pemanfaatan Teknologi Informasi Dalam Pembelajaran Online Masa Covid-19', Cetta: Jurnal Ilmu Pendidikan, vol. 3, no. 2, Art. no. 2, Jun. 2020, doi: 10.37329/cetta.v3i2.452.

[10] A. D. Dumford and A. L. Miller, 'Online learning in higher education: exploring advantages and disadvantages for engagement', J Comput High Educ, vol. 30, no. 3, pp. 452465, Dec. 2018, doi: 10.1007/s12528-0189179-z.

[11] L. D. Herliandry, N. Nurhasanah, M. E. Suban, and H. Kuswanto, 'Pembelajaran Pada Masa Pandemi Covid-19', JTP - Jurnal Teknologi Pendidikan, vol. 22, no. 1, Art. no. 1, Apr. 2020, doi: 10.21009/jtp.v22i1.15286.

[12] A. W. Irawan, D. Dwisona, and M. Lestari, 'Psychological Impacts of Students on Online Learning During the Pandemic COVID-19', KONSELI: Jurnal Bimbingan dan Konseling (E-Journal), vol. 7, no. 1, Art. no. 1, May 2020, doi: 10.24042/kons.v7i1.6389.

[13] D. L. Bandalos and S. J. Finney, 'Factor Analysis: Exploratory and Confirmatory', in The Reviewer's Guide to Quantitative Methods in the Social Sciences, 2nd ed., Routledge, 2018.

[14] J. T. Y. Tsang, M. K. P. So, A. C. Y. Chong, B. S. Y. Lam, and A. M. Y. Chu, 'Higher Education during the Pandemic: The Predictive Factors of Learning Effectiveness in COVID19 Online Learning', Education Sciences, vol. 11, no. 8, Art. no. 8, Aug. 2021, doi: 10.3390/educsci11080446.

[15] O. Isaac, A. Aldholay, Z. Abdullah, and T. Ramayah, 'Online learning usage within Yemeni higher education: The role of compatibility and task-technology fit as mediating variables in the IS success model', Computers \& Education, vol. 136, pp. 113129, Jul. 2019, doi: 10.1016/j.compedu.2019.02.012.

[16] R. P. Rahayu and Y. Wirza, 'Teachers' Perception of Online Learning during Pandemic Covid-19', Jurnal Penelitian Pendidikan, vol. 20, no. 3, Art. no. 3, Dec. 2020, doi: 10.17509/jpp.v20i3.29226.

[17] M. D. B. Castro and G. M. Tumibay, 'A literature review: efficacy of online learning courses for higher education institution using meta-analysis', Educ Inf Technol, vol. 26, no. 2, pp. 1367-1385, Mar. 2021, doi: 10.1007/s10639-019-10027-z. 